\title{
Disperse Systems Based on a Dodecyl Derivative of $p$-Sulfonatocalix[6]arene: Self-Organization and Physicochemical Properties in a Wide Range of Concentrations and Temperatures
}

\author{
Irina S. Ryzhkina ${ }_{1}{ }^{@}$ Yulia V. Kiseleva, ${ }^{a}$ Lyaisan I. Murtazina ${ }_{1}{ }^{a}$ Svetlana E. Solovieva, ${ }^{a}$ \\ Nikolay G. Manin, ${ }^{\mathrm{b}}$ and Alexander I. Konovalov ${ }^{\mathrm{a}}$ \\ ${ }^{a}$ A.E. Arbuzov Institute of Organic and Physical Chemistry, Kazan Scientific Center, Russian Academy of Sciences, \\ 420088 Kazan, Russian Federation \\ ${ }^{\mathrm{b}}$ G.A. Krestov Institute of Solution Chemistry, Russian Academy of Sciences, 153045 Ivanovo, Russian Federation \\ @Corresponding authorE-mail: ryzhkina@iopc.ru
}

\begin{abstract}
Using a complex of physicochemical methods it has been shown for the first time that the diluted solutions $\left(10^{-11}-10^{-3} \mathrm{M}\right)$ of dodecyl derivative of p-sulfonatocalix [6] arene are disperse systems, where the role of a disperse phase is played by the supramolecular structures of different nature - micelles (above $6 \cdot 10^{-4} \mathrm{M}$ ), domains $\left(1 \cdot 10^{-4}-1 \cdot 10^{-7} \mathrm{M}\right.$ ) and nanoassociates $\left(1 \cdot 10^{-9}-1 \cdot 10^{-8} \mathrm{M}\right)$. The disperse phase's parameters change nonmonotonically as systems dilution, what results in the decrease of surface tension at concentrations lower than the critical micelle concentration and determines the differences in systems' behaviour at various temperatures $\left(15-60^{\circ} \mathrm{C}\right.$ ) and hold up times (after 8 months).
\end{abstract}

Keywords: Sulfonatocalix[6]arene, dodecyl derivative, aqueous disperse systems, self-organization, physicochemical properties.

\section{Аисперсные системы на основе додецильного производного n-сульфонатокаликс[6]арена: самоорганизация и физико-химические свойства в широком интервале концентраций и температур}

\author{
И. С. Рыжкина, ${ }^{a}{ }^{@}$ Ю. В. Киселева, ${ }^{a}$ Л. И. Муртазина, ${ }^{a}$ С. Е. Соловьева, ${ }^{a}$ \\ Н. Г. Манин, ${ }^{\text {b }}$ А. И. Коновалов ${ }^{\text {a }}$ \\ ${ }^{\mathrm{a}}$ Федеральное государственное бюджетное учреждение науки Институт органической и физической химии \\ им. А.Е. Арбузова Казанского научного иентра Российской академии наук, 420088 Казань, Российская Федераиия \\ ${ }^{\mathrm{b}}$ Федеральное государственное бюджетное учреждение науки Институт химии растворов им. Г.А. Крестова \\ Российской академии наук, 153045 Иваново, Российская Федераичи \\ @E-mail:ryzhkina@iopc.ru
}

\begin{abstract}
Впервые комплексом физико-химических методов показано, что разбавленные растворы $\left(10^{-11}-10^{-3} \mathrm{M}\right)$ додецильного производного п-сульфонатокаликс[6]арена представляют собой дисперсные системы, дисперсной фазой в которых являются супрамолекулярные структуры различной природы - мицелль (выле 6·10-4 M), домень $\left(1 \cdot 10^{-4}-1 \cdot 10^{-7}\right.$ M) и наноассоциаты $\left(1 \cdot 10^{-9}-1 \cdot 10^{-8} \mathrm{M}\right)$. Параметры дисперсной фазы немонотонно изменяются по мере разбавления систем, что вызывает снижение поверхностного натяжения при концентрациях, ниже критической концентраџии мищеллообразования, а также обусловливает отличия в поведении систем при различных температурах $\left(15-60^{\circ} \mathrm{C}\right)$ и времени выдерживания (по истечении 8 месяцев).
\end{abstract}

Ключевые слова: Сульфонатокаликс[6]арен, додецильное производное, водные дисперсные системы, самоорганизация, физико-химические свойства. 


\section{Introduction}

A new recently developed experimental approach to studying highly diluted aqueous solutions $\left(10^{-20}-10^{-6} \mathrm{M}\right)$ has allowed to explain for the first time the reasons that account for the emergence of nonmonotonic changes of their physicochemical and some of the biological properties. ${ }^{[1-3]}$ As a result of a comparative study of self-organization and properties of a diverse series of biologically active substances' solutions, prepared using the method of successive decimal dilution and exposed both to natural conditions (being kept on the laboratory bench) and to the full absence of external low-frequency electromagnetic fields (EMF) (being kept in a permalloy container), it has been shown that the diluted solutions of many biologically active substances (BAS) are in fact the disperse systems, where the role of the disperse phase is played by supramolecular ensembles of different nature - at first these are the small substance aggregates and supramolecular domains, while with dilution below the threshold concentration $\left(C_{\mathrm{th}}\right)$ they reorganize into nanoassociates of hundreds of $\mathrm{nm}$ in size. It is shown that it is this kind of reorganization that is responsible for the nonmonotonic concentration dependencies of the systems' physicochemical properties, and not the decrease in the initial substance's concentration. In case of the systems with the low initial substance's concentration, the term "concentration" involves that it is a calculated value, used to characterize systems prepared as a result of dilution of an initial system of a known molar concentration.

The supramolecular domains and nanoassociates are formed with the participation of water molecules, but they consist of them in a different ratio, e.g. the nanoassociates they are clearly dominant, being a sensor for the lowfrequency EMFs. ${ }^{[4]}$ The size of hundreds of nanometers in the case of the nanoassociates points out that millions of water molecules take part in their formation. A specified structure of the BAS is also required for their formation, apart from the presence of external EMFs and the special preparation procedure. ${ }^{[1]}$

Utilizing the above-described original approach for studying the disperse systems allowed for an experimentally proved differentiation of the disperse phase's nature, which often has a similar size of hundreds of nanometers, and it also can be useful for studying the supramolecular systems containing BAS of complex structure, e.g. the systems based on an intensively studied in the last decades calixarenes, ${ }^{[5-7]}$ for which a complicated nonmonotonic change of the physicochemical properties is often observed with the decrease in concentration. Studies ${ }^{[8-10]}$ managed to explain the causes of nonmonotonic changes in the concentration dependencies of the specific electrical conductivity, surface tension, and bioeffects in water-organic systems based on amphiphilic calix[4]resorcinols $\left(10^{-4}-10^{-7} \mathrm{M}\right)$ and amphiphilic acetylhydrazide derivative of 4-tert-butyltetrathiacalix[4]arene in the cone and 1,3-alternate conformations $\left(10^{-4}-10^{-8} \mathrm{M}\right)$ from the perspective of formation and rearrangement of supramolecular domains and nanoassociates.

Calixarenes are synthetically available complexly organized tridimensional macrocyclic phenols that model the receptor, transport and catalytic functions of complex biomolecules. ${ }^{[11,12]}$ Calixarenes containing hydrophilic and hydrophobic groups are the amphiphilic molecules, capable of self-organizing and forming supramolecular ensembles of different kinds. ${ }^{[5,11,12]}$ In the last decades much attention is given to exploring synthesis methods, the properties and possible use cases of $p$-sulfonatocalix[n]arenes (SCA) and their derivatives. ${ }^{[5,11,13-19]}$ One of the most promising usage scenarios lies in the biomedical sphere. ${ }^{[20,21]}$ This is aided by the SCA's high solubility in water, low toxicity ${ }^{[20]}$ and availability for functionalization, which allows for controlling the physicochemical properties by changing the nature of the substituting groups and the number of aromatic rings. For example, appending the alkyl radicals to the SCA molecule results in the change of its hydrophilic-lipophilic balance and the emergence of the surfactant properties. ${ }^{[13-15]}$ The increased number of aromatic rings translates into the conformational flexibility of the macrocycle, ${ }^{[5,11]}$ leading to the emergence of an adaptive capability of substrate fixation (flexible "adjustment"). However, despite the large number of publications dedicated to $p$-sulfonatocalix[n] arenes, the processes of self-organization and the physicochemical properties of the alkylated SCA's solutions in a wide range of concentrations (including the low ones), have not been yet systematically studied.

The aim of this work was to study the self-organization and properties of a water-soluble dodecyl derivative of the $p$-sulfonatocalix[6] arene (1) that has a vast scope of applications ${ }^{[5-7]}$ using a complex of physicochemical methods (dynamic light scattering - DLS, nanoparticle tracking analysis - NTA, tensiometry, differential scanning calorimetry - DSC), which can help to find the concentration ranges of different disperse phases' formation, define their behavior patterns and explain the properties of 1 solutions in a wide range of concentrations $\left(1 \cdot 10^{-11}-1 \cdot 10^{-3} \mathrm{M}\right)$, temperatures $\left(10-90{ }^{\circ} \mathrm{C}\right)$ and storage times.

\section{Experimental}

The synthesis of the calixarene $\mathbf{1}$ was carried out following a known procedure. ${ }^{[6]}$ The data of IR and ${ }^{1} \mathrm{H}$ NMR spectra of 1 corresponded to the previously published ones. ${ }^{[6]}$ The preparation and study of systems based on $\mathbf{1}$ was carried out using a fresh bidistilled water, specific conductivity of which was no more than $1.5 \mu \mathrm{Sm} / \mathrm{cm}$. The systems based on 1 were prepared by the method of successive decimal dilutions from an initial substrate's solution of concentration of $1 \cdot 10^{-2} \mathrm{M}$ analogous to.$^{[1]}$ The particles' size (the effective hydrodynamic diameter of kinetically labile particles at the maximum of the distribution curve, D) was determined by the method of dynamic light scattering (DLS) on a highsensitive analyzer Zetasizer Nano ZS ("Malvern Instruments", Great Britain). With the purpose of particles' visualization as well as determining their size and quantity in $1 \mathrm{~mL}$ of the solution, the systems based on $\mathbf{1}$ have been elucidated using the nanoparticles tracking analysis method (NTA) on the NanoSight LM 10 analyzer ("NanoSight Instruments", Great Britain) in the HS-BF configuration analogous to. ${ }^{[22]}$ The surface tension $(\sigma)$ in the water-air system was studied using the Du Nouy anchorring method. The measurement of $\sigma$ by the Du Nouy method was carried out on a high-precision Sigma 702 ET tensiometer (KSV Instruments), equipped with a thermostatically-controlled jacket, whose resolving power corresponds to $0.001 \mathrm{mN} / \mathrm{m}$, using a platinum-iridium ring with a radius of $9.545 \mathrm{~mm}$ and a wire radius of $0.185 \mathrm{~mm}$. 
<smiles>[R]Oc1c(CC(C)(C)C)cc(S(=O)(=O)O)cc1C(C)(C)C</smiles>

The study of the EMF influence on the self-organization and properties of aqueous solutions was carried out in the following way - the 1-based system of each examined concentration in the course of 24 hours was simultaneously exposed to: 1) natural conditions on the laboratory bench, 2) screening conditions of a three-layer permalloy container which protects its contents against the influence of external EMFs.

The heat capacities of the diluted aqueous systems based on $\mathbf{1}$ with concentrations of $1 \cdot 10^{-3}, 1 \cdot 10^{-4}, 1 \cdot 10^{-5}, 1 \cdot 10^{-6}, 1 \cdot 10^{-7}, 1 \cdot 10^{-8}$ and $1 \cdot 10^{-9} \mathrm{M}$ were elucidated on an adiabatic differential scanning microcalorimeter Skall in the temperature range of $10-90{ }^{\circ} \mathrm{C}$, the scanning speed being equal to $1 \mathrm{~K} / \mathrm{min}$ and the step of $0.5^{\circ} \mathrm{C}$ in three repeated measurements. Additionally, after eight months from the preparation of $\mathbf{1}$ solutions the measurements of their heat capacities were repeated under the same conditions. Experimental data were processed using the standard programs of Excel software package, particle size measurement errors $-\leq 15 \%$, errors in the measurement of physicochemical properties $-\leq 3 \%$.

\section{Results and Discussion}

The study of the systems based on 1 using the DLS method has shown that at the concentration of $1 \cdot 10^{-3} \mathrm{M}$ the particle size distribution is bimodal, the sizes being approximately 35 and $270 \mathrm{~nm}$. As stated before, ${ }^{[6]}$ the former are micelles, and the critical micelle concentration $(\mathrm{CMC})$ is $6 \cdot 10^{-4} \mathrm{M}$. In the concentration range from $1 \cdot 10^{-9}$ to $1 \cdot 10^{-4} \mathrm{M}$ the distribution has a monomodal character, there are particles of a nonmonotonically changing size from

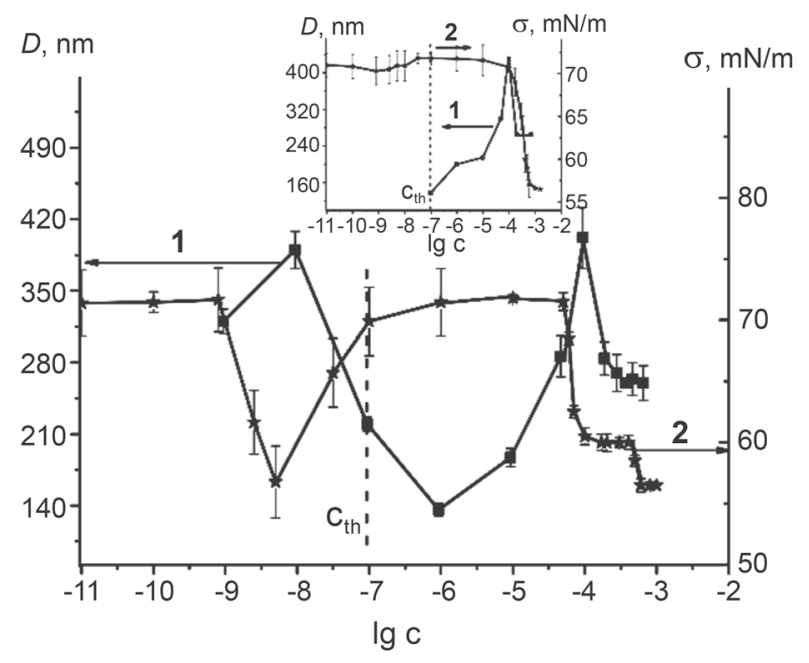

Figure 1. Dependence of the size of particles (D) (1) formed in aqueous solutions of $\mathbf{1}$, and the surface tension $(\sigma)(2)$ of systems exposed to natural conditions, on the concentration, $25{ }^{\circ} \mathrm{C}$. The inset shows the dependence of the particle size (1) and the surface tension (2) of systems held in hypoelectromagnetic conditions on the concentration of $1,25^{\circ} \mathrm{C}$. $C_{\text {th }}$ is the threshold concentration.
140 to $380 \mathrm{~nm}$ forming in the system (Figure 1, curve 1). The limit of particle detection in the 1-based systems by the DLS method is reached at $1 \cdot 10^{-9} \mathrm{M}$. The maximum particle size value is at concentrations of $1 \cdot 10^{-4}$ and $1 \cdot 10^{-8} \mathrm{M}$, the minimum - at $1 \cdot 10^{-6} \mathrm{M}$.

The studies of systems based on $\mathbf{1}$, exposed both to natural and hypoelectromagnetic conditions, have shown that the threshold concentration is $1 \cdot 10^{-7} \mathrm{M}$ (Figure 1, inset, curve 1). This means that particles of a size of hundreds of $\mathrm{nm}$, formed in the interval $1 \cdot 10^{-7}-1 \cdot 10^{-3} \mathrm{M}$, are domains, and in the interval $1 \cdot 10^{-9}-1 \cdot 10^{-8} \mathrm{M}-$ nanoassociates. Thus, the $\mathbf{1}$ solutions are disperse systems, the role of the disperse phase in which is played by supramolecular structures of different nature - micelles (above CMC $6 \cdot 10^{-4} \mathrm{M}$ ), domains (above $\left.1 \cdot 10^{-7} \mathrm{M}\right)$, and nanoassociates $\left(1 \cdot 10^{-9}-1 \cdot 10^{-8} \mathrm{M}\right)$.

The formation of particles with a size of hundreds of $\mathrm{nm}$ in the disperse systems based on diluted solutions of $\mathbf{1}$ was confirmed by the NTA method, which makes it possible to determine the size and number of particles in $1 \mathrm{ml}$ of the solution, and also to visualize them. ${ }^{[22,23]}$ The NTA method can be used for particles in the range from $10 \mathrm{~nm}$ to $1 \mu \mathrm{m}$, with the number of particles from $10^{7}$ to $10^{9}$ in a milliliter of solution. For the study of systems based on $\mathbf{1}$ using the NTA method, concentrations of $1 \cdot 10^{-5}, 1 \cdot 10^{-6}, 1 \cdot 10^{-8}$, $1 \cdot 10^{-9} \mathrm{M}$ were chosen. It was found that particles in the range of tens and hundreds of $\mathrm{nm}$ are visualized in all the solutions studied (Figure 2). The number of particles in a milliliter of solution at $1 \cdot 10^{-5} \mathrm{M}$ (Figure $2 \mathrm{a}$ ) exceeds $10^{10}$, what makes it impossible to accurately determine their size by the NTA method. At $1 \cdot 10^{-6}, 1 \cdot 10^{-8}, 1 \cdot 10^{-9} \mathrm{M}$, the number of particles in $1 \mathrm{ml}$ of the solution in order of decreasing concentration of 1 is $4 \cdot 10^{8}, 8 \cdot 10^{8}, 2 \cdot 10^{8}$, their average diameter being 80 , 170 and $150 \mathrm{~nm}$ (Figure 2b-d). The number of particles in bidistilled water is less than $1 \cdot 10^{6}$ in $1 \mathrm{ml}$, which lies outside the sensitivity range of the device. Thus, it was discovered that nanoassociates of the largest size and in the largest amount are formed in dilute solutions of $\mathbf{1}$ at a concentration of about $1 \cdot 10^{-8} \mathrm{M}$.

An important fact is that when the calculated concentration of $\mathbf{1}$ decreases by an order of magnitude from $1 \cdot 10^{-5}$ to $1 \cdot 10^{-6} \mathrm{M}$, within which domains exist, the number of particles in $\mathrm{ml}$ decreases by almost two orders of magnitude. A further decrease in the concentration of 1 by two orders of magnitude from $1 \cdot 10^{-6}$ to $1 \cdot 10^{-8} \mathrm{M}$ and again by an order of magnitude to $1 \cdot 10^{-9} \mathrm{M}$, within which the nanoassociates are formed, is accompanied by a nonmonotonic change in the number of particles by a factor of $2-4$. On the one hand, the obtained result confirms that the self-organization of highly dilute solutions is a complex nonlinear process that is not directly related to the concentration of the solute, and on the other hand it indicates that the formation of an unusual dispersed phase - nanoassociates of tens and hundreds of $\mathrm{nm}$ size - is primarily due to molecules of water with minimal participation of molecules of the substance.

A study of surface tension in the concentration range $1 \cdot 10^{-15}-1 \cdot 10^{-3} \mathrm{M}$ showed (Figure 1, curve 2) that the surface tension isotherm has a stepped nature, containing two plateaus in the $\mathrm{CMC}$ region $\left(6 \cdot 10^{-4} \mathrm{M}\right)$ and in the region of domains' formation $\left(1 \cdot 10^{-4}-4 \cdot 10^{-4} \mathrm{M}\right)$ (Figure 1, curve 2). In addition, in the interval $5 \cdot 10^{-8}-3 \cdot 10^{-9} \mathrm{M}$ with an extremum at $6 \cdot 10^{-9} \mathrm{M}$, i.e. approximately in the region of formation 
a

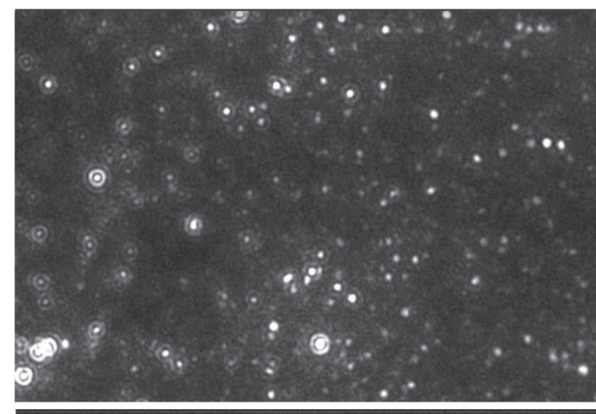

$\mathrm{b}$

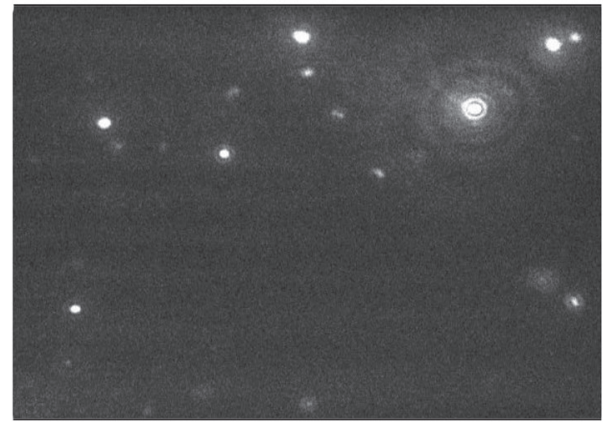

$\mathrm{c}$

d

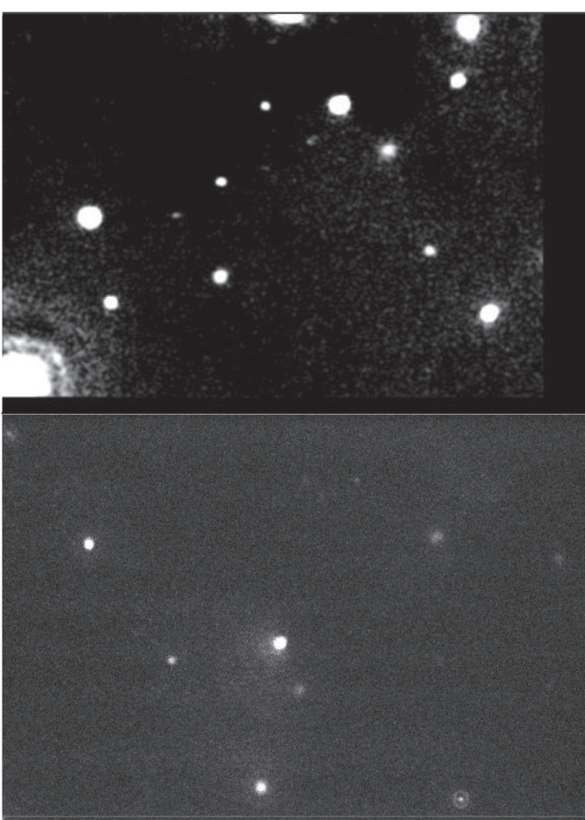

Figure 2. Images of aqueous solutions of 1 obtained by the NTA method at concentrations of 1 equal to $1 \cdot 10^{-5} \mathrm{M}(\mathrm{a}), 1 \cdot 10^{-6} \mathrm{M}(\mathrm{b})$, $1 \cdot 10^{-8} \mathrm{M}(\mathrm{c}), 1 \cdot 10^{-9} \mathrm{M}(\mathrm{d}), 25^{\circ} \mathrm{C}$.

of nanoassociates with the maximum size and number, a sharp decrease in the $\sigma$ of the solution to $57 \mathrm{mN} / \mathrm{m}$ is also observed.

In systems maintained under hypoelectromagnetic conditions, the region of local reduction of $\sigma$ at a concentration of $6 \cdot 10^{-9} \mathrm{M}$ and a plateau in the region of $1 \cdot 10^{-4}-4 \cdot 10^{-4} \mathrm{M}$ disappears on the surface tension isotherm (Figure 1, inset, curve 2), i.e. the surface tension isotherm acquires a classical form with one inflection in the CMC region, which is inherent in the solution of surfactants in which micelles are formed. ${ }^{[24]}$

The results obtained jointly by the methods of DLS, NTA and tensiometry about the size, number of domains and nanoassociates and surface tension in the interval $1 \cdot 10^{-9}-1 \cdot 10^{-3} \mathrm{M}$ make it possible to make an assumption about the causes of the appearance of an unusual type of surface tension isotherm in the low concentration region. Reduction of $\sigma$ in the intervals of domains and nanoassociates formation, i.e. at $1 \cdot 10^{-4}-4 \cdot 10^{-4} \mathrm{M}$ and $6 \cdot 10^{-9} \mathrm{M}$, is associated with a significant rearrangement that the disperse system undergoes with dilution. In the region of these concentrations, the domain size increases sharply, and in the case of nanoassociates not only the size, but also the number, which probably leads to the expulsion of amphiphilic molecules of $\mathbf{1}$ from the dispersion medium to the water-air interface and to a decrease in the surface tension of the system (Figure 1, curves 1 and 2). Thus, as the dilution proceeds, a structural rearrangement of the dispersed system as a whole takes place, i.e. both of the dispersed phase and the dispersion medium, which is most pronounced in the concentration ranges of about $1 \cdot 10^{-4}-1 \cdot 10^{-5} \mathrm{M}$ and $1 \cdot 10^{-7}-1 \cdot 10^{-9} \mathrm{M}$.

In order to obtain additional information on the structural rearrangement of the system $\mathbf{1}$ and the properties of the dispersed phase in various ranges of concentrations and temperatures, the heat capacity of aqueous systems based on 1 in the concentration range $1 \cdot 10^{-3}-1 \cdot 10^{-9} \mathrm{M}$ in the range of $10-90{ }^{\circ} \mathrm{C}$ was studied by differential scanning microcalorimetry, as well as of $\mathbf{1}$ systems, subjected to long-term storage (for 8 months). From the experimentally observed specific heat capacity of the solution $\left(c_{P}\right)$, the excess partial specific heat of $\mathbf{1}$ in an aqueous solution $\left(c_{P, 2}^{E}\right)$ was found and analyzed, calculated analogous to ${ }^{[25,26]}$, which is the differential characteristic of the dissolved substance that most clearly reflects the structural rearrangements in the solution with respect to the dissolved substance, associated

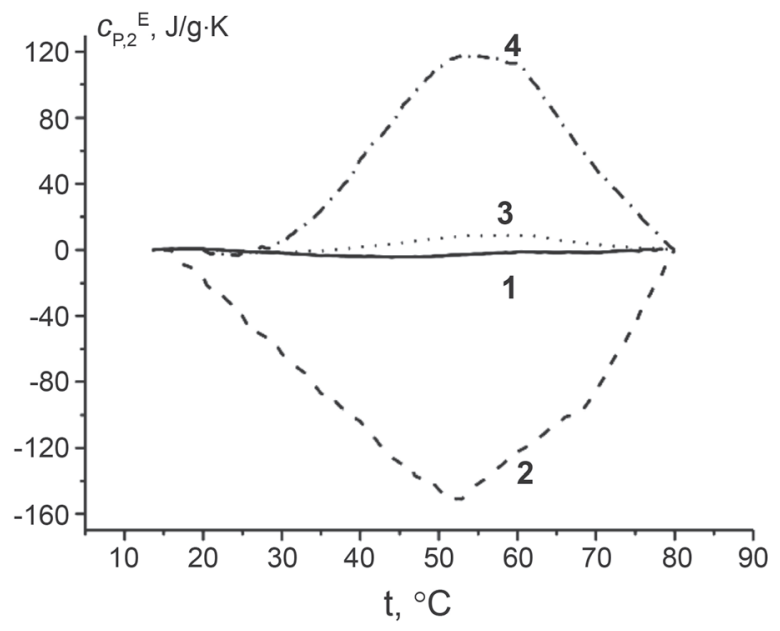

Figure 3. Dependences of the excess partial specific heat $c_{P, 2}^{E}$ of aqueous solutions of $\mathbf{1}$ on temperature at concentrations equal to $1 \cdot 10^{-4} \mathrm{M}(1), 1 \cdot 10^{-5} \mathrm{M}(2), 10^{-7} \mathrm{M}(3), 10^{-8} \mathrm{M}(4)$. For solutions with a concentration of $1 \cdot 10^{-4} \mathrm{M}$ and $1 \cdot 10^{-5} \mathrm{M}$, the dimension of $c_{P, 2}^{E}$ is in $\mathrm{J} / \mathrm{g} \cdot \mathrm{K}$. 
with the formation and destruction of the associates of "dissolved substance - solute" and "dissolved substance solvent" kinds.

The dependence of $c_{P, 2}^{E}$ on the temperature at various concentrations of $\mathbf{1}$ is shown in Figure 3. As can be seen from the data in this figure, the value of $c_{P, 2}^{E}$ varies differently with different concentrations with the temperature growth, being both positive (curve 1,2) and negative (curve 3,4), which may be due to the structural rearrangements in the system in different concentration intervals.

The curve of the temperature dependence of $c_{P, 2}^{E}$ (Figure 3) reflects structural transitions in the system, excluding information on the temperature dependences of the heat capacity of the initial and final (after structural changes) states. The temperature dependence of the heat capacity before and after the peak is practically linear, and the change in the heat capacity between the initial and final transition states is close to zero. As can be seen from the data in Figure 3, with a decrease in the concentration of $\mathbf{1}$ from $10^{-4} \mathrm{M}$ to $10^{-8} \mathrm{M}$, a change in $c_{P, 2}^{E}$ as a function of temperature is observed in different sign and magnitude, probably related to the different nature of the domains and nanoassociates formed in the region of these concentrations.

At concentrations of $1 \cdot 10^{-4} \mathrm{M}$ and $1 \cdot 10^{-5} \mathrm{M}$, the $c_{P, 2}^{E}$ value is negative in the range from $15{ }^{\circ} \mathrm{C}$ to $80{ }^{\circ} \mathrm{C}$, with an absolute value of $c_{P, 2}^{E}$ at a lower solution concentration of $1 \cdot 10^{-5} \mathrm{M}$ being substantially higher $\left(c_{P, 2}^{E}<-151 \mathrm{~J} / \mathrm{g} \cdot \mathrm{K}\right)$ than at $1 \cdot 10^{-4} \mathrm{M}\left(c_{P, 2}^{E}<-4.4 \mathrm{~J} / \mathrm{g} \cdot \mathrm{K}\right)$ (Figure 3 , curves 1,2$)$. The observed decrease in the heat capacity of $\mathbf{1}$ with increasing temperature, most pronounced for $1 \cdot 10^{-5} \mathrm{M}$, can be due to the thermally induced domain rearrangement, which leads to the formation of more ordered structures.

As follows from the data in Figure 1, at $25^{\circ} \mathrm{C}$ with a decrease in the concentration of $\mathbf{1}$ by an order of magnitude from $1 \cdot 10^{-4} \mathrm{M}$ to $1 \cdot 10^{-5} \mathrm{M}$, a sharp decrease in the domain size from 380 to $140 \mathrm{~nm}$ occurs as well as the change in the properties of the system, whose surface tension at $1 \cdot 10^{-5} \mathrm{M}$ increases to a value of $72 \mathrm{mN} / \mathrm{m}$, which corresponds to the $\sigma$ of water. The different state of the dispersed system at $1 \cdot 10^{-4} \mathrm{M}$ to $1 \cdot 10^{-5} \mathrm{M}$ probably causes a different kind of curves $c_{P, 2}^{E}=f(\mathrm{~T})$ at these concentrations of 1 . The domains formed at $1 \cdot 10^{-5} \mathrm{M}$ are more sensitive to an increase in temperature, under the influence of which considerable changes are undergone, which may be due to a decrease in the number of molecules of $\mathbf{1}$ and an increase in the fraction of water structures in the domain, i.e. changing its packing density and size. ${ }^{[22]}$ In this case, a temperature of $\sim 50{ }^{\circ} \mathrm{C}$, corresponding to the minimum value of $c_{P, 2}^{E}$ leads to the greatest structural organization of domains in solution.

A further decrease in the concentration of 1 leads, as the temperature increases, to an increase in the positive value of $c_{P, 2}^{E}$ (Figure 3, curves 3, 4), reaching the maximum at $1 \cdot 10^{-8} \mathrm{M}$ (at $\left.1 \cdot 10^{-9} \mathrm{M} c_{P, 2}^{E} \sim 0\right)$. As can be seen from the data in Figure 1, at $25{ }^{\circ} \mathrm{C}$ the system undergoes significant rearrangements with extrema in the size of nanoassociates and surface tension also at the concentration of $1 \cdot 10^{-8} \mathrm{M}$. Thus, the observed increase in $c_{P, 2}^{E}$ with increasing temperature, most pronounced for $1 \cdot 10^{-8} \mathrm{M}$, can be due to the rearrangement of nanoassociates, accompanied by opposing effects, compared with the domain formation interval.
The change in the sign of the $c_{P, 2}^{E}$ curve with increasing temperature upon transition from the systems in which the domains are formed to the systems in which nanoassociates are formed is probably associated not only with the different nature of nanoassociates and domains, but also with various processes taking place in the system as a whole, which can exert significant influence on the behavior of systems when interacting with biomembranes. For example, the study of dilute solutions of potassium phenozane antioxidant (PP) by the DSC method showed that the PP solutions used in the range of formation of domains and nanoassociates ${ }^{[2,3]}$ change the thermostability of the protein fraction of plasma membranes in the opposite direction - in the domain formation range, it increases, and in the nanoassociation formation region it is reduced. ${ }^{[27]}$

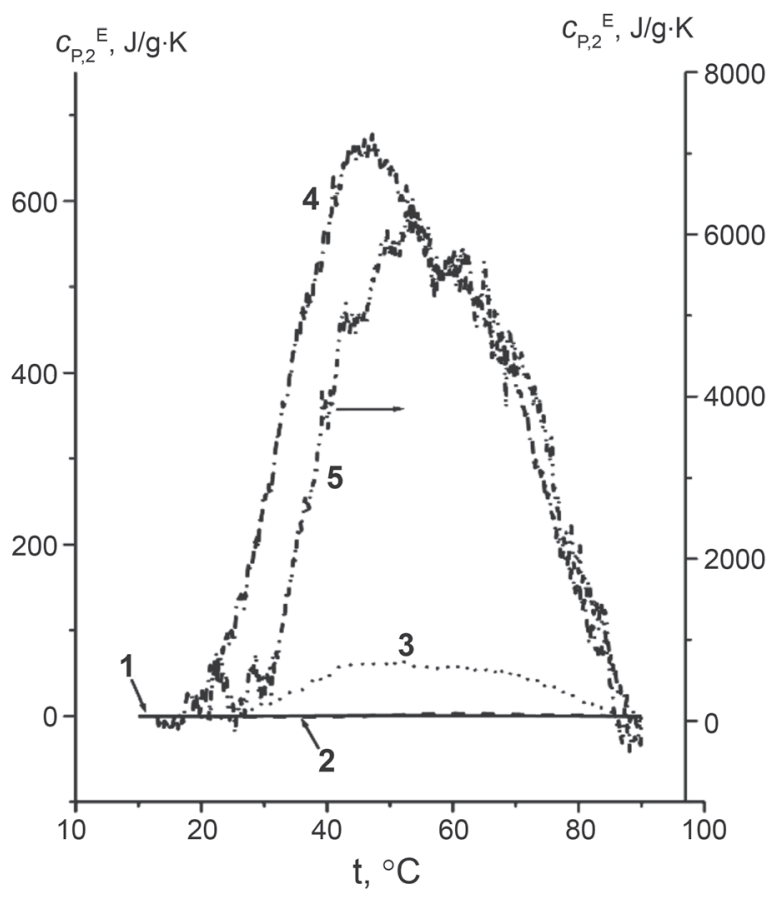

Figure 4. Dependence of $c_{P, 2}^{E}$ of aqueous solutions on temperature eight months later after preparation of solutions at concentrations equal to $1 \cdot 10^{-4} \mathrm{M}(1), 1 \cdot 10^{-5} \mathrm{M}(2), 1 \cdot 10^{-6} \mathrm{M}(3)$, $1 \cdot 10^{-7} \mathrm{M}(4), 1 \cdot 10^{-8} \mathrm{M}(5)$.

Both domains and nanoassociates, starting at $\mathrm{t}>55^{\circ} \mathrm{C}$, are destroyed, the maximum deviations from additivity are observed in both cases in the $50-60{ }^{\circ} \mathrm{C}$ interval. Therefore, the peak on the $c_{P, 2}^{E}=f(\mathrm{~T})$ curve for aqueous systems based on $\mathbf{1}$ in the range from $1 \cdot 10^{-5} \mathrm{M}$ to $1 \cdot 10^{-8} \mathrm{M}$ at $50-55^{\circ} \mathrm{C}$ is a criterion for the presence of domains and nanoassociates in the solution formed by the dissolved substance and water structures, as well as the criterion of their temperature stability. All changes in $c_{P, 2}^{E}$ appear up to $60{ }^{\circ} \mathrm{C}$, and at a higher temperature they start to level or disappear, what indicates the destruction of nanoassociates and domains with increasing temperature. Probably, nanoassociates are stronger $\left(c_{P, 2}^{E} \sim 120 \mathrm{~kJ} / \mathrm{g} \cdot \mathrm{K}\right)$ than domains $\left(c_{P, 2}^{E} \sim 150 \mathrm{~J} / \mathrm{g} \cdot \mathrm{K}\right)$.

At the end of eight months after their preparation, the systems based on $\mathbf{1}$ retained a positive deviation of the 
excess partial specific heat of the solute with increasing temperature in the concentration range $1 \cdot 10^{-6}-1 \cdot 10^{-8} \mathrm{M}$ (Figure 4, curves 3-5). In contrast to the freshly prepared systems (Figure 3 ), positive deviations in the concentration range $1 \cdot 10^{-4}-1 \cdot 10^{-5} \mathrm{M}$ were also observed with a temperature increase of $c_{P, 2}^{E}<0.75 \mathrm{~J} / \mathrm{g} \cdot \mathrm{K}$ for $1 \cdot 10^{-4}$ and $c_{P, 2}^{E}<3.8 \mathrm{~J} / \mathrm{g} \cdot \mathrm{K}$ for $1 \cdot 10^{-5} \mathrm{M}$. The increase in the positive value of $c_{P, 2}^{E}$ in the concentration range $1 \cdot 10^{-6}-1 \cdot 10^{-8} \mathrm{M}$ indicates the stability of nanoassociates in time, and the absence of $c_{P, 2}^{E}<0$ in the concentration range from $1 \cdot 10^{-4} \mathrm{M}$ to $1 \cdot 10^{-5} \mathrm{M}-$ on lower temporal stability of the formed domains.

\section{Conclusions}

Thus, as a result of a research which studied the selforganization and properties of a dodecyl derivative of $p$-sulfonatocalix[6]arene (1) in a wide range of calculated concentrations $1 \cdot 10^{-11}-1 \cdot 10^{-3} \mathrm{M}$ utilizing a complex of physicochemical methods it has been shown for the first time that such solutions are disperse systems, where the role of a disperse phase is played by the supramolecular structures of different nature - micelles (above $6 \cdot 10^{-4} \mathrm{M}$ ), domains $\left(1 \cdot 10^{-4}-1 \cdot 10^{-7} \mathrm{M}\right)$ and nanoassociates $\left(1 \cdot 10^{-9}-1 \cdot 10^{-8} \mathrm{M}\right)$. The parameters of the dispersed phase vary nonmonotonically with dilution, what causes differences in the behavior of the systems at different temperatures $\left(15-60^{\circ} \mathrm{C}\right)$ and aging time (after 8 months)

Acknowledgements. The authors thank E.G. Evtushenko (Lomonosov Moscow State University, Chemistry Department) for help in conducting measurements by the NTA method.

\section{References}

1. Konovalov A.I., Ryzhkina I.S. Russ. Chem. Bull. 2014, 60(1), $1-14$.

2. Ryzhkina I.S., Kiseleva Yu.V., Murtazina L.I., Konovalov A.I. Dokl. Phys. Chem. 2012, 446(1), 153-157.

3. Konovalov A., Ryzhkina I., Maltzeva E., Murtazina L., Kiseleva Yu., Kasparov V., Palmina N. Electromagn. Biol. Med. 2015, 34(2), 141-146.

4. Lobyshev V.I. Zh. Vser. Khim. Obshchestva im. D.I. Mendeleeva 2007, 51, 107-114. (in Russ.).

5. Mandolini L., Ungaro R. Calixarenes in Action. London: Imperial College Press, 2000. $271 p$.
6. Ryzhkina I.S., Kiseleva Yu.V., Solov'yeva S.E., Pilishkina L.M., Valitova Yu.N., Konovalov A. Russ. Chem. Bull. 2009, 58(12), 2506-2511.

7. Ryzhkina I.S., Kiseleva Yu.V., Murtazina L.I., Valitova Yu.N., Solov'yeva S.E., Pilishkina L.M., Konovalova A.I. Russ. Chem. Bull. 2010, 59(7), 1327-1335.

8. Ryzhkina I.S., Kiseleva Yu.V., Mishina O.A., Murtazina L.I., Sudakova S.N., Podyachev S.N., Konovalov A.I. Dokl. Phys. Chem. 2013, 453(1), 264-269.

9. Ryzhkina I.S., Kiseleva Yu.V., Mishina O.A., Masagutova E.M., SergeevaS.Yu., Sudakova S.N.,Podyachev S.N., KonovalovA.I. Russ. Chem. Bull. 2014, 63(6), 1399-1408.

10. Ryzhkina I.S., Kiseleva Yu.V., Mishina O.A., Voloshina A.D., Kulik N.V., Valitova Yu.N., Sudakova S.N., Podyachev S.N., Zobov V.V., Konovalov A.I. Dokl. Phys. Chem. 2015, 464(2), 251-254.

11. Asfari Z., Bohmer V., Harrowfield J., Vicens J. Calixarenes 2001. Dordrecht-Boston-London: Kluwer Academic Publishers, 2001. $683 p$.

12. Casnati A., Sansone F., Ungaro R. Acc. Chem. Res. 2003, 36, 246.

13. Shinkai S., Mori S., Tsubaki T., Sone T., Manabe O. Tetrahedron Lett. 1984, 25(46), 5315-5318.

14. Shinkai S. Pure Appl. Chem. 1986, 58(11), 1523-1528.

15. Shinkai S., Mori S., Koreshi H., Tsubaki T., Manabe O. J. Am. Chem. Soc. 1986, 108, 2409-2416.

16. Shinkai S., Arimura T., Araki K., Kawabata H. J. Chem. Soc. Perkin Trans. I 1989, 2039-2045.

17. Scharff J.P., Mahjoubi M. New J. Chem. 1991, 15, 883-887.

18. Arduini A., Casnati E., Dalcanale E., Pochini A., Ugozzoli F., Ungaro R. Calixarenes and Resorcinarenes in Molecular Recognition and Supramolecular Devices. Supramolecular Science: Where It Is and Where It Is Going. Dordrecht-BostonLondon: Kluwer Academic Publishers, 1999. p. 67-79.

19. Coleman A.W., Bott S.G., Morley S.D., Means C.M., Robinson K.D., Zhang H., Atwood J.L. Angew. Chem. 1988, 27, 1361-1367.

20. Peret F., Lazar A., Coleman A.W. Chem. Commun. 2006, 23, 2425-2438.

21. Cleman A.W., Jebors S., Cecillon S., Perret P. New J. Chem. 2008, 32, 780-782.

22. Ryzhkina I.S., Kiseleva Yu.V., Mishina O.A., Murtazina L.I., Litvinov A.I., Kadirov M.K., Konovalov A.I. Russ. Chem. Bull. 2015, 64(3), 579-589.

23. Filipe V., Hawe A., Jiskoot W. Pharm. Res. 2010, 27(5), 796-810.

24. Holmberg K., Jonsson B., Kronberg B., Lindman B. Surfactants and Polymers in Aqueous Solution. 2nd ed., New York-London: John Wiley \& Sons, Ltd., 2003. p. 527.

25. Filimonov V.V., Potekhin S.A., Matveev S.V., Privalov P.L. Molekul. Biol. (USSR) 1982, 26, 551-562.

26. Privalov P.L., Potekhin S.A. Methods Enzym. 1986, 131, 1-51.

27. Kozlov S.S., Chasovskaya T.E., Semenova M.G., Palmina N.P. Dokl. Biochem. Biophys. 2014, 459(1), 190-193. 